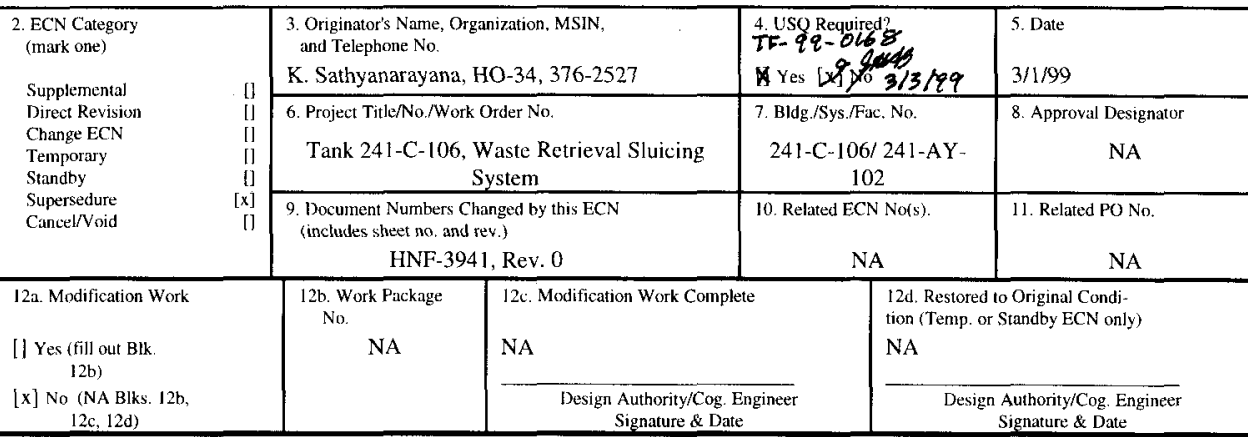

13a. Description of Change

13b. Design Baseline Document? [] Yes [ $\mathrm{x}$ ] No

This ECN provides revisions to HNF-3941, Rev 0. The revisions are made in response to comments made by the Tank Review

Group. Revisions are highlighted in Rev 1 document.

\begin{tabular}{|llllllll} 
14.3. Justification (mark one) & & & & & \\
Criteria Change & {$[\mathrm{x}]$} & Design Jmprovement & II & Environmental & [] & Facility Deactivation \\
As-Found & {[]} & Facilitate Const & [I] & Const. Error/Omission & {[]} & Design Error/Omission & [] \\
\hline
\end{tabular}

14b. Justification Details

The changes made to HNF-3941, Rev 0 were required resolve review comments of the TRG. Changes have been reviewed and approved by TRG.

15. Distribution (include name, MSIN, and no. of copies)

See attached list.

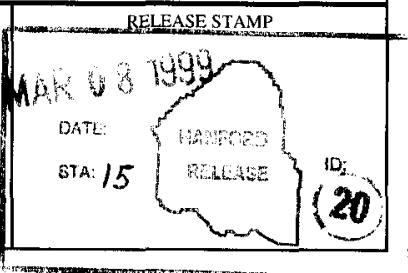




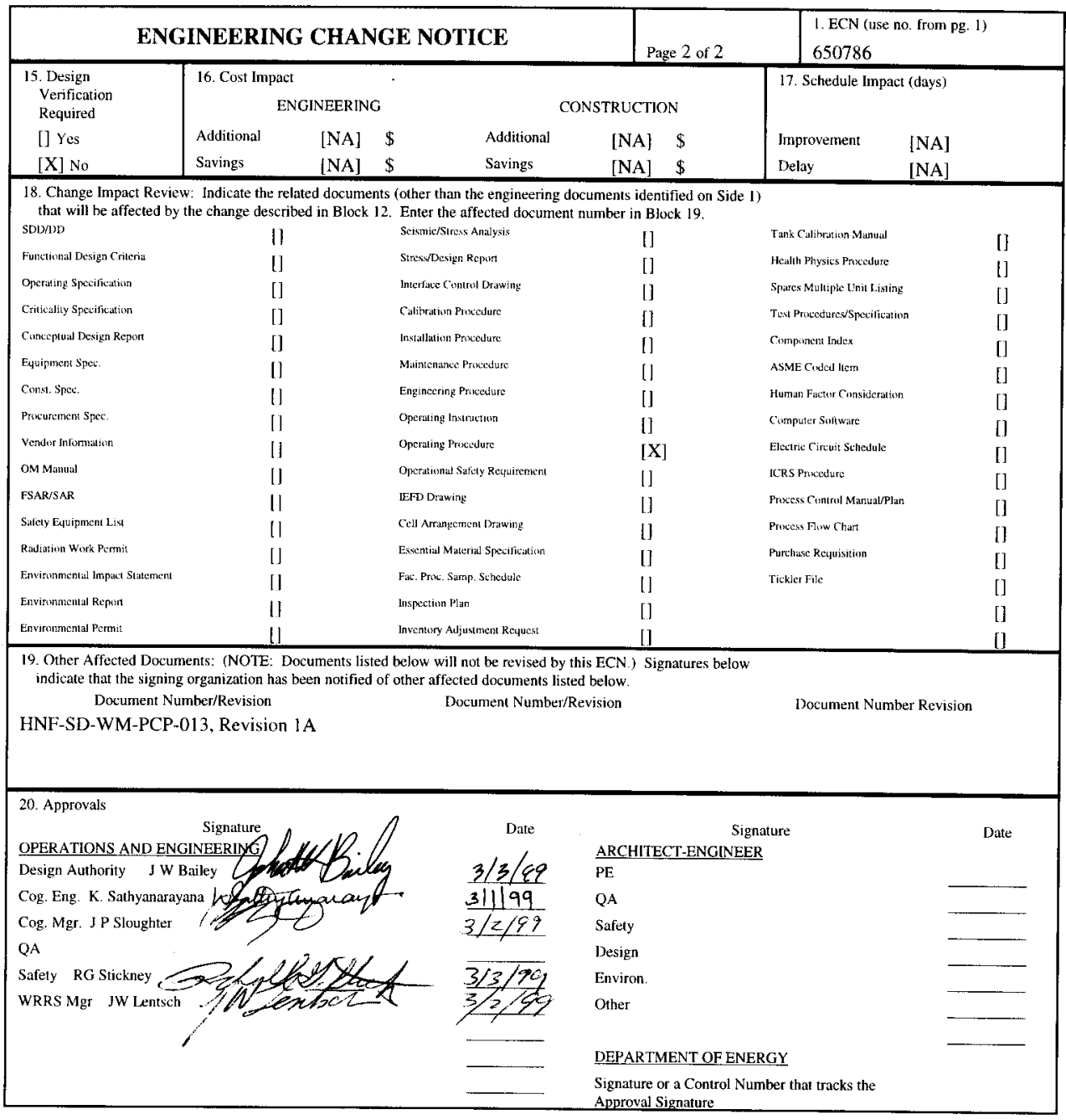




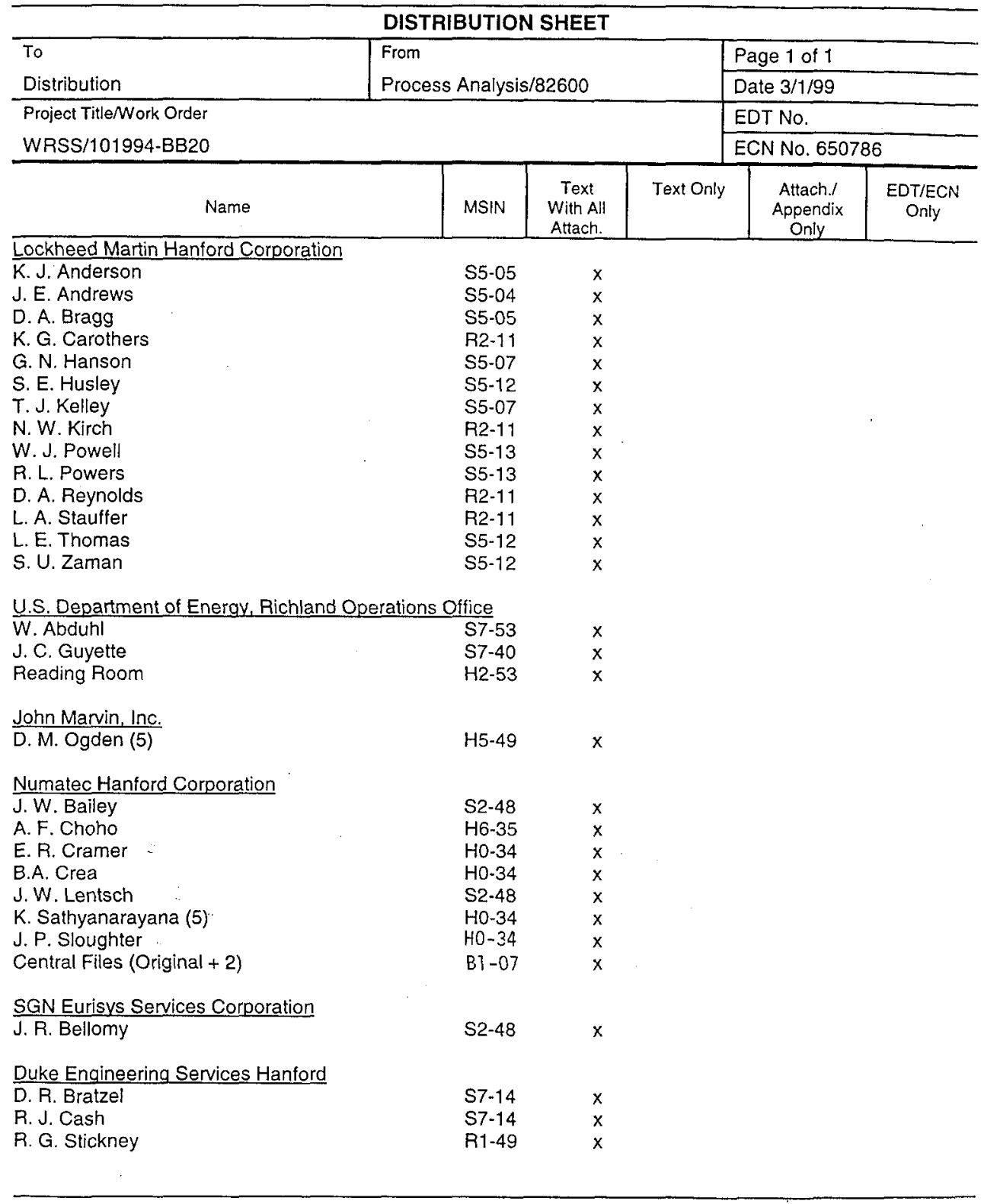




\section{EVALUATION OF RISER 14 TEMPERATURE RESPONSE}

\section{M. Ogden}

John Marvin, Inc., West Richland, WA 99353

\section{K. Sathyanarayana}

Numatec Hanford Company, Richland, WA 99352

\section{E. R. Cramer}

Numatec Hanford Company, Richland, WA 99352

U.S. Department of Energy Contract DE-AC06-96RL13200

$\begin{array}{lll}\text { EDT/ECN: } 650786 & \text { UC: } 512 & \\ \text { Org Code: } 82600 & \text { Charge Code: } 101994 / \mathrm{BB} 20 & \text { HN920581 } \\ \text { B\&R Code: EW3130010 } & \text { Total Pages:28 } 28 & \end{array}$

Key Words: Thermal Analyses, 241-C-106, Riser 14, Project WRSS

Abstract: The initial sluicing activities of Project WRSS resulted in a two month increase in temperatures as measured by the Riser 14 thermocouple tree of tank 241-C-106. While this increase was anticipated, the maximum temperature was higher than expected. An evaluation was performed to determine if adequate subcooling exists in the waste to continue sluicing activities. It was determined that a minimum of $10^{\circ} \mathrm{F}$ subcooling exists in the waste and that the higher Riser 14 temperatures were the result of higher than assumed waste saturation temperature.

TRADEMARK DISCLAIMER. Reference herein to any specific commercial product, process, or service by trade name, trademark, manufacturer, or otherwise, does not necessarily constitute or imply its endorsement, recommendation, or favoring by the United States Government or any agency thereof or its contractors or subcontractors.

Printed in the United States of America. To obtain copies of this document, contact: Document Control Services, P.O. Box 950, Mailstop H6-08, Fichland WA 99352, Phone (509) 372-2420; Fax (509) 376-4989.

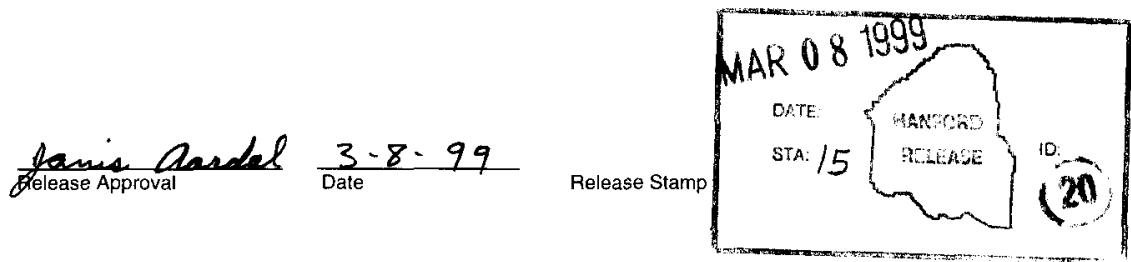

\section{Approved for Public Release}




\section{RECORD OF REVISION}

(2) Title

EVALUATION OF RISER 14 TEMPERATURE RESPONSE

\section{CHANGE CONTROL RECORD}

$\begin{array}{ll}\text { (3) Revision } & \text { (4) Description of Change - Replace, Add, and Delete Pages }\end{array}$

1 RS $\quad$ Revision per ECN 650786

Authorized for Release

\begin{tabular}{|c|c|c|c|}
\hline+2 & (7) Desenple & (5) Cog. 5 & (6) Cog Mgr. \\
\hline $1 \mathrm{RS}$ & Revision per ECN 650786 & K. Sathygraraya & JP Slougl 184 \\
\hline & & & \\
\hline & & & \\
\hline & & & \\
\hline & & & \\
\hline & & & \\
\hline & & & \\
\hline & & & \\
\hline & & & \\
\hline & & & \\
\hline & & & \\
\hline & & & \\
\hline & & & \\
\hline & & & \\
\hline & & & \\
\hline & & & \\
\hline & & & \\
\hline & & & \\
\hline & & & \\
\hline & & & \\
\hline & & & \\
\hline & & & \\
\hline & & & \\
\hline & & & \\
\hline & & & \\
\hline
\end{tabular}


HNF-3941, Rev I

\title{
EVALUATION \\ OF RISER 14 \\ TEMPERATURE RESPONSE
}

\author{
D.M. Ogden \\ John Marvin, Inc. \\ Richland, Washington \\ K. Sathyanarayana \\ E.R. Cramer \\ Numatec Hanford Corporation \\ Richland, Washington
}

lssued by

Numatec Hanford Corporation

Richland, Washington

For the

\section{U.S. DEPARTMENT OF ENERGY \\ RICHLAND OPERATIONS OFFICE \\ RICHLAND, WASHINGTON}




\section{TABLE OF CONTENTS}

1.0 INTRODUCTION 3

2.0 HISTORICAL C-106 THERMAL EVENTS............................................................... 4

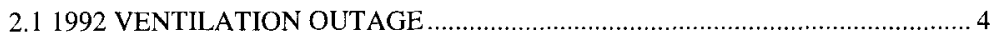

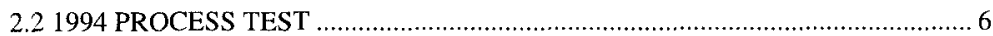

2.3 INITIAL TEMPERATURE FOR PROCESS CONTROL ANALYSES.................. 7

3.0 PROCESS CONTROL ANALYSES...................................................................... 9

4.0 EVALUATION OF THE RISER 14 TEMPERTURES.......................................... 13

4.1 PREDICTED MAXIMUM WASTE TEMPERATURE ….................................. 13

4.2 EVALUATION OF THE WASTE SATURATION TEMPERATURE …….......... 14

4.3 RECOMMENDED REVISION FOR RISER 14 TEMPERATURE LIMIT .......... 16

5.0 CONCLUSIONS ......................................................................................................... 18

6.0 REFERENCES......................................................................................................... 19

APPENDIX A THERMAL ISSUE RESOLUTION MEETING MINUTES ............ 20

\section{FIGURES}

Figure 1 C-106 Dome Temperature for 1992 Ventilation Outage..................................... 5

Figure 2 Supernate Level for 1992 Ventilation Outage .................................................... 5

Figure 3 GOTH Prediction of 1994 Process Test Without Steam Generation. ................. 6

Figure 4 GOTH Prediction with Steam in Waste ……............................................... 7

Figure 5 Benchmark Analyses of Dome Temperature ................................................... 10

Figure 6 Benchmark Analyses of Riser 8, TCl Temperatures....................................... 11

Figure 7 Process Control Model Predicted Waste Subcooling....................................... 12

Figure 8 Riser 14, TC1 And Predicted Maximum Waste Temperatures.......................... 14

Figure 9 Temperature Response of Thermocouples 1 \& 2 of Riser 14........................... 23

Figure 10 Effects of Barometric Pressure on Riser 14 Temperature ............................... 24

Figure 11 Barometric Pressure Effects ................................................................... 25

Figure 12 Pressure - Temperature Correlation............................................................ 26

\section{TABLES}

Table 1 Saturation Temperature Estimates Based 1996 Samples................................... 15 


\subsection{INTRODUCTION}

On November 10, 1998 the temperatures measured by the Riser 14-thermocouple tree, began increasing from a normal operating temperature near $125^{\circ} \mathrm{F}$ as measured by thermocouple 1(TC1). The temperature of TCl increased to $225^{\circ} \mathrm{F}$ over the next two months. The sluicing activities in the tank were expected to eliminate convective cooling at the location of Riser 14, resulting in the observed temperature increase. However, the measured waste temperatures at Riser 14 exceed the maximum waste temperatures predicted by the thermal process control model. They also exceeded the maximum temperature limit for Riser 14 of $218{ }^{\circ} \mathrm{F}$. This was unexpected. An evaluation was subsequently performed. The purpose of the evaluation was to determine why the measured Riser 14 temperatures were higher than expected and whether sufficient subcooling existed in the waste to continue sluicing activities. The evaluation considered previous thermal transients for tank $241-\mathrm{C}-106$, a review of the process control model and assumed initial conditions, and a re-assessment of the waste saturation temperature.

The evaluation concluded that the bulk of the waste was subcooled by at least $10^{\circ} \mathrm{F}$. While best estimate thermal analyses indicate that all the waste is subcooled, small portion of the waste, with saturation temperatures lower than the bulk waste, could be at or near saturation temperatures. However, spontaneous steam bumps did not occur during the 1992 ventilation outage or the 1994 process test when significant regions of the waste were at saturation. With liquid pool covering during the first increment of sluicing to prevent mechanical disruption near the tank bottom, small regions will not present a risk of a steam bump. The under-prediction of the maximum waste temperature was the result of a low estimate of the waste saturation temperature. Revised estimate of the saturation temperature is $5^{\circ} \mathrm{F}$ higher than previous estimate.

Two thermal transients for tank 241-C-106 are discussed in Section 2.0. An evaluation of these thermal transients provides the initial conditions for the process control analyses.

The results of the process control analyses are presented in Section 3.0. Both the predicted waste subcooling and maximum waste temperatures are presented. The Riser 14 temperature response is presented in Section 4.0. This includes a re-evaluation of the waste saturation temperature. Conclusions of the Riser 14 temperature evaluation are provided in Section 5.0. 


\subsection{HISTORICAL C-106 THERMAL EVENTS}

Tank 241-C-106 has experienced two thermal transients beyond normal tank operation. In 1992, an unplanned ventilation outage occurred which resulted in a total loss of ventilation for nearly six months. The tank waste experiences a significant heat-up during this ventilation outage. In 1994, a process test was conducted which eliminated water additions to the tank for a period of four months. The waste surface was uncovered which decreased the supernate evaporation. Both events resulted in off-normal thermal transients. The evaluation of these thermal transients has provided useful information about the tank waste temperatures.

\subsection{VENTILATION OUTAGE}

In January of 1992, the tank 241-C-106 ventilation system was out of operation for nearly six months. The loss of ventilation resulted in a significant tank heat-up. The measured dome space temperatures are shown in Figure 1. The dome space temperatures increased to over $150^{\circ} \mathrm{F}$. Thermal analyses were performed using the GOTHIC computer code and the computer model used for the process control thermal analyses. The model accounts for buoyancy driven natural convection flows. The predicted dome temperatures agree well with measured data as shown in Figure 1. A second calculation was performed which eliminated evaporative cooling 80 days after the loss of ventilation. The predicted dome temperature is shown in Figure 1. The second analyses demonstrates that evaporative cooling, resulting from the natural convection flow, is required to predict the dome temperatures.

Figure 2 shows the measured and predicted supernate level. The level drops after the loss of ventilation (for about 3 weeks) but then increases until ventilation flow is reestablished. The predicted level is based upon the water loss from evaporation. The difference between the measured and predicted level is attributed to a significant volume of waste reaching saturation temperature which was previously subcooled. Vapor was trapped in the waste resulting in an increase in the supernate level. Small portions of the waste may have been at, or near saturation temperature, prior to the loss of ventilation. These regions should be small, however, since the supernate level was not significantly affected for several weeks after the loss of ventilation.

Based upon the evaluation of the 1992 ventilation outage, it is appropriate to assume that the bulk of the waste was subcooled by a minimum $5^{\circ} \mathrm{F}$ in the winter of 1992 prior to the ventilation outage.

\footnotetext{
${ }^{1}$ Gothic is proprietary software of the Electric Power Research Institute.
} 


\section{Figure 1 C-106 Dome Temperature for 1992 Ventilation Outage}

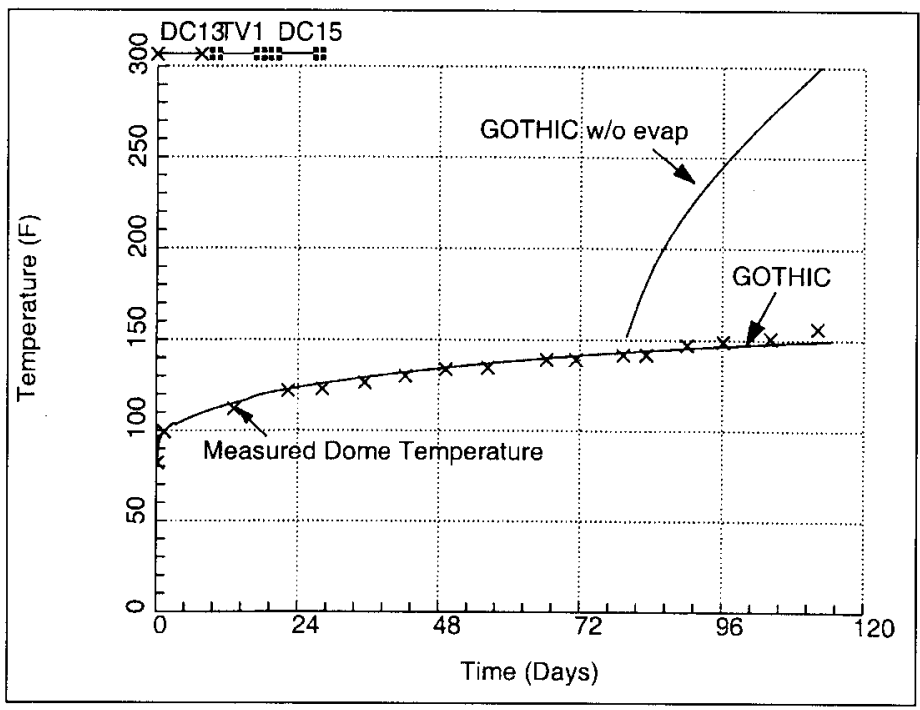

Figure 2 Supernate Level for 1992 Ventilation Outage

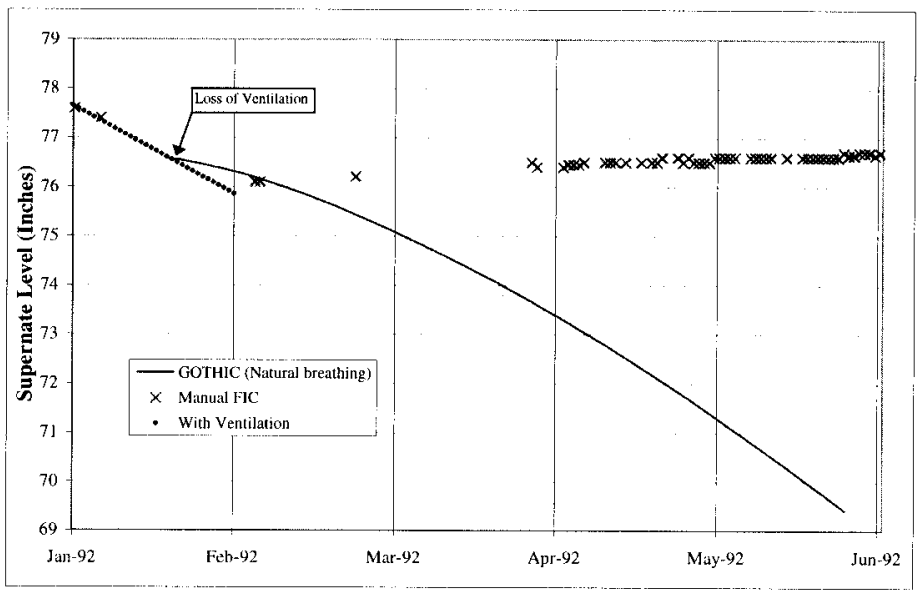


Figure 3 GOTH Prediction of 1994 Process Test Without Steam Generation.

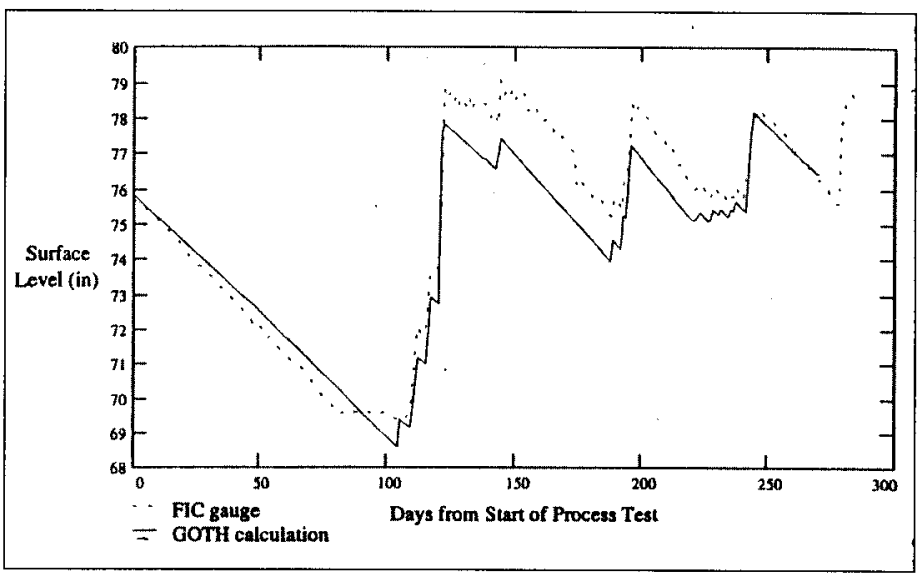

\subsection{PROCESS TEST}

A similar behavior was observed following the 1994 tank 241-C-106-process test. Evaluation of the 1994 process test (Bander 1995) demonstrated that waste temperatures in a significant volume of waste had reached saturation temperatures, resulting in vapor storage in the waste and an increase in waste volume. This effect is shown in Figure 3. No water additions occurred during the process test that resulted in the initial level decrease shown in the figure. The waste was uncovered for approximately 30 days, which decreased the waste cooling (decreased evaporation). Water additions, 100 days after the start of the process test, brought the level to near 79 inches. However, GOTH analyses which modeled that actual volume of added water (with boiling disabled for the analyses), showed a discrepancy between the measured level and the expected level, based upon the water additions.

When the GOTH analyses were repeated, allowing steam formation, the predicted level agreed well with the measured level as shown in Figure 4. The increase in waste volume from the expansion of the waste closed a small cooling channel surrounding the Riser 14thermocouple tree. With the loss of liquid convective cooling, the local waste temperatures increased as a result of conduction heat transfer. Thus, a significantly larger portion of the tank 241-C-106 waste was at saturation temperature following the 1994process test. The maximum temperature for the bulk waste was then just at or below waste saturation temperature for summer condition in 1994. As stated in the previous section, small portion of waste could have been at or near saturation temperature prior to the 1994 process test but are expected to be small. 
Based upon the evaluation of the 1994 process test, it is appropriate to assume that the maximum temperature of the bulk waste was just at or below saturation temperature for summer condition in 1994. This is consistent with $5^{\circ} \mathrm{F}$ subcooling in winter of 1992 (roughly $7{ }^{\circ} \mathrm{F}$ increase in subccoling for winter conditions, with several degree reduction in subcooling for the higher heat load in 1992).

Figure 4 GOTH Prediction with Steam in Waste

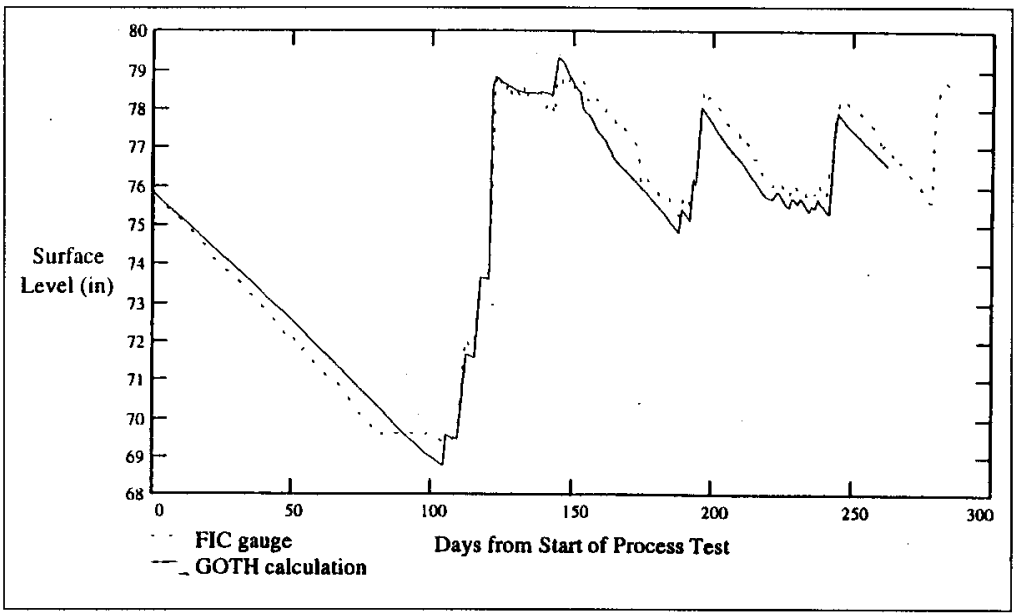

\subsection{INITIAL TEMPERATURE FOR PROCESS CONTROL ANALYSES}

The analyses discussed in the Sections 2.1 and 2.2 demonstrate that the C-106 maximum waste temperatures were below saturation temperatures, in the bulk of the waste, during the winter of 1992 and before summer of 1994. The thermal transients resulting from the 1992 ventilation outage and the 1994-process test increased the waste temperature to waste saturation temperatures in a significant volume of waste. This establishes a starting condition for the process control analyses discussed in Section 3.0. The waste saturation temperature was estimated using chemical composition of waste samples (Reynolds 1994). A saturation temperature estimate of $230^{\circ} \mathrm{F}$ was used for the process control thermal analyses.

It should be noted that thermal analyses assume the waste is homogeneous with respect to the saturation temperature. The evaluation of the thermal transients show that on average the waste was below the saturation temperature as previously discussed. This does not however rule out the possibility that small regions of the waste may have lower saturation temperatures or a higher local heat generation than the bulk of the waste. These regions 


\section{HNF-3941, Rev 1}

could be near or at saturation when the bulk waste is subcooled. However, as discussed in Section 2.1 and 2.2, these regions are believed to be small if they exist and the use of the saturation temperature for the maximum temperature of the bulk waste is appropriate. 


\subsection{PROCESS CONTROL ANALYSES}

The waste subcooling is not measured directly at the location of the maximum waste temperature (centerline bottom of the tank). The Waste Retrieval Sluicing System (WRSS) Process Control Plan (Carothers et al. 1998) stipulates that thermal analyses shall be performed to determine the subcooling of the maximum temperature waste for tank 241-C-106. A description of the thermal model and the benchmark of the model with tank data are provided in Ogden et al.1998a. The thermal model benchmark results are shown in Figures 5 and 6 . A comparison of the predicted dome space temperature with data is shown in Figure 5. The analyses through December of 1996 were performed with monthly average data. The remainder of the analyses used daily ambient conditions. The agreement is excellent for over three years of data. This parameter is related directly to the heat load of the tank and the operation of the tank ventilation systems, which was included in the analyses. This provides a good benchmark of the process control thermal model. Figure 6 shows a comparison with TC1 of the Riser 8 thermocouple tree. The agreement of the analyses with data is again very good, which further demonstrates that the thermal process control model predicts the thermal behavior of tank 241-C-106 and can be used for the intended process control analyses.

Figure 7 shows the predicted subcooling for the $241-\mathrm{C}-106$ waste at the location of the maximum waste temperature. This is the process control parameter of interest in the thermal analyses. As discussed in Section 2.3, the subcooling (temperature difference between waste and saturation temperature) of the maximum temperature waste, following the 1994 process test, was set to zero. This is seen in Figure 7 in July of 1994. The initial temperature of the thermal model was selected to agree with this reference waste condition. The analyses account for the ambient conditions (ambient temperature shown in the figure), radionuclide decay and tank ventilation system operation. The seasonal variation is clearly seen in the analyses. The maximum summer temperatures for 1997 were higher than previous years. This resulted in lower winter subcooling in 1998. The 296-P-16 ventilation chiller operation was initiated 1998 as shown. Without the operation of the chiller, the subcooling would have been reduced to below summer 1997 conditions as a result of the high summer 1998 temperatures. The sluicing ventilation system (296-C-006) operation was initiated in October of 1998. The decrease in subcooling near the end of the analyses is a result of the re-circulation system heater operation. These effects are predicted by the model and consistent with the ambient data and tank ventilation operation. 
Figure 5 Benchmark Analyses of Dome Temperature.

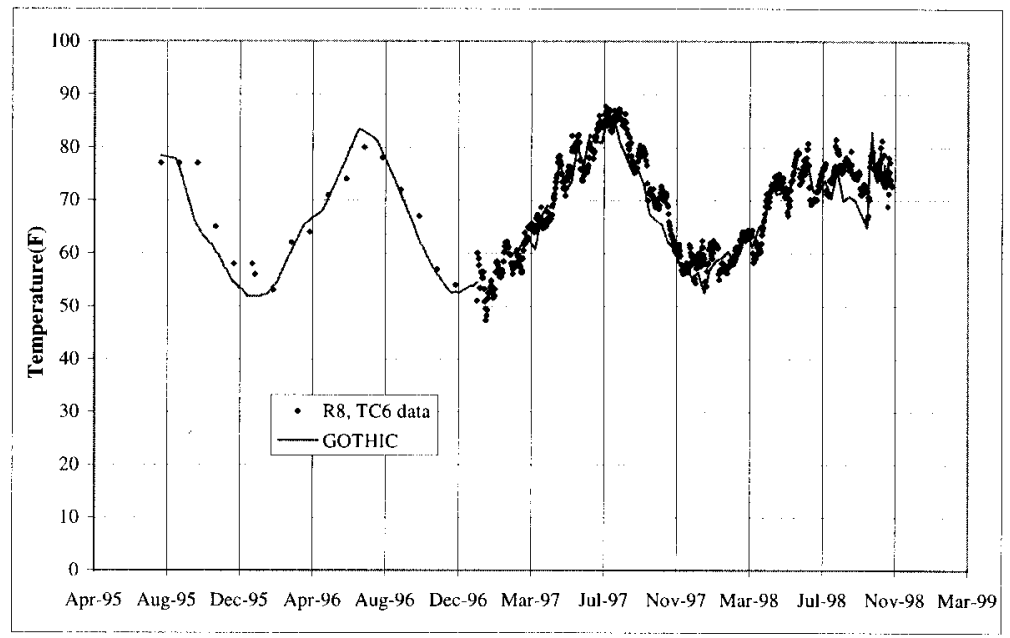

The predicted subcooling at the initiation of sluicing was $11^{\circ} \mathrm{F}$. This is a credible estimate of the subcooling based upon the benchmark of the process control model shown in Figures 5 and 6. Predicting the change in temperature since the 1994 process test provides the predicted subcooling estimate. A waste saturation temperature of $230^{\circ} \mathrm{F}$ was used for the thermal analyses. This number was based upon an evaluation of the expected vapor suppression in the waste (Reynolds 1994). The estimate of the saturation temperature will be discussed in the Section 4. 0. However, the prediction of the temperature change and therefore the waste subcooling is independent of this estimated saturation temperature. Since the thermal analysis is initiated at this temperature for 1994 summer conditions, the maximum predicted temperatures for current tank conditions would increase or decrease directly with a change in the initial temperature. The predicted subcooling however will remain unchanged.

As discussed in the previous section, the process control thermal analyses applies to the bulk waste. The bulk waste subcooling has increased to over $10^{\circ} \mathrm{F}$ since the 1994 process test. All the waste is expected to be subcooled. Some temperature oscillations of Riser 14 seem to be correlated to barometric pressure changes as discussed in Appendix A. This could indicate that waste very near that thermocouple tree was at or near waste saturation temperature at $225^{\circ} \mathrm{F}$, although there may be other plausible explanations (see Appendix A) . The material near Riser 14 settled near the tree because of the initial sluicing activities. The material came from the upper portions of the waste that had been exposed to frequent water additions. It is therefore not representative of the bulk waste 
and could have a lower saturation temperature. It should also be noted that inhomogeneity in waste saturation temperature or local heat generation may exist in other portion of the tank. Small regions of waste could be at or near saturation although the maximum temperature of the bulk waste is substantially subcooled. The ventilation outage of 1992 and 1994 process test demonstrated that spontaneous steam bumps have not occurred in this tank, even when substantial portion of the waste was saturated. However, there is a concern that a mechanical disruption of a saturated region of waste may induce a steam bump. For this reason, a liquid pool will be maintained over the waste sludge surface during the first campaign of sluicing. This will prevent the mechanical disruption of the waste near the regions of maximum temperature and eliminate the potential for steam bumps through the disruption of small regions of saturated waste. In addition, the $10^{\circ} \mathrm{F}$ subcooling that now exist in the bulk waste will help assure that any saturation regions resulting from waste in-homogeneity are small.

Figure 6 Benchmark Analyses of Riser 8, TC1 Temperatures.

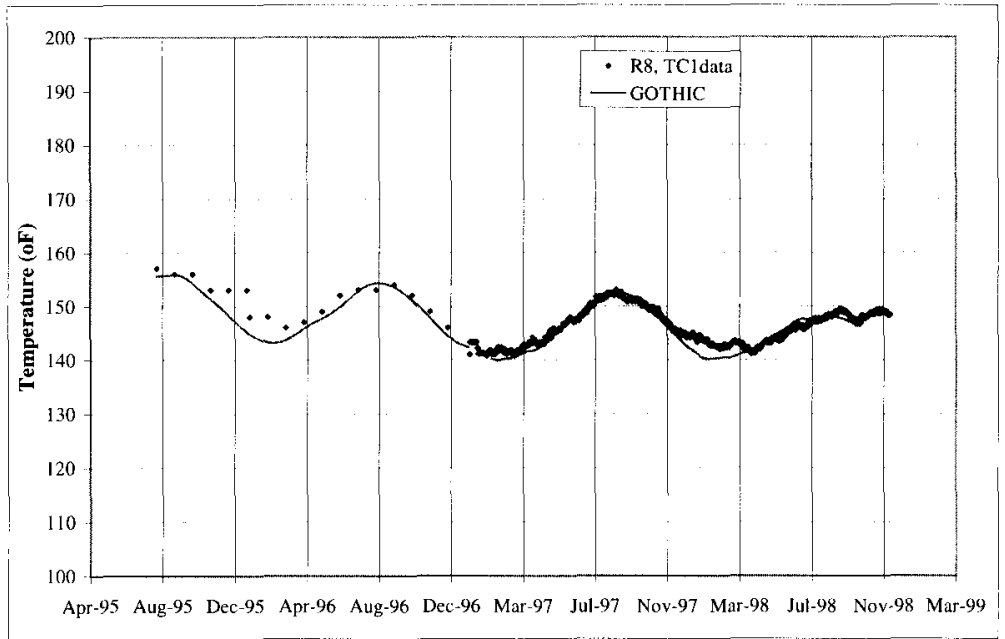


HNF-3941, Rev 1

Figure 7 Process Control Model Predicted Waste Subcooling.

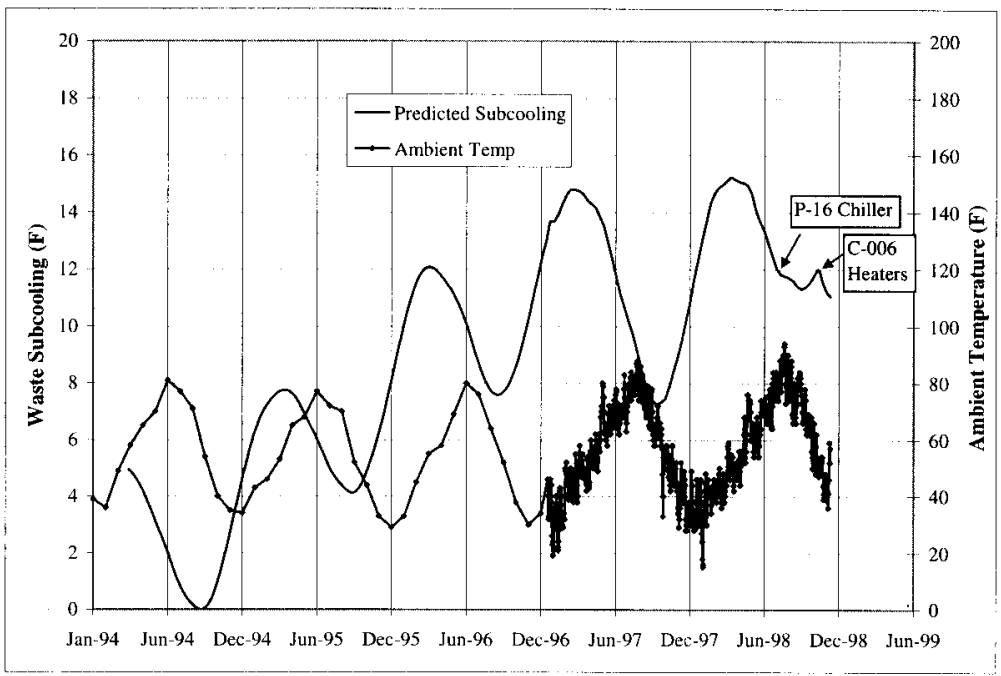


HNF-3941, Rev 1

\subsection{EVALUATION OF THE RISER 14 TEMPERTURES}

The Riser 14 temperature anomalies observed following the 1994 process test were attributed to the waste expansion resulting from steam generation in the waste (Section 2.2). This closed the convective gap around the Riser 14 thermocouple tree. A similar behavior was anticipated during the sluicing of tank 241-C-106 and was documented in the WRSS safety documentation (FDH 1998). It was expected that waste would fill in the gap during the mixing of waste in the supernate pool. This would eliminate liquid convection and produce the Riser 14-temperature behavior observed following the 1994 process test.

\subsection{PREDICTED MAXIMUM WASTE TEMPERATURE}

The predicted maximum waste temperature, based upon a waste saturation temperature of $230^{\circ} \mathrm{F}$, is shown in Figure 8. The measured temperatures for TC1 of the Riser 8 and 14 thermocouple trees are also shown. The Riser 14, TC1 measured temperature was lower than Riser $8 \mathrm{TC} 1$ prior to sluicing. This is the evidence of liquid convection around the tree since a conduction heat transfer solution requires the temperature to be higher near the center (Riser 14) of the tank than near the tank wall (Riser 8). Immediately following the initial sluicing, the Riser 14, TCl temperatures began to increase, reaching a maximum temperature of $225^{\circ} \mathrm{F}$ (shown in Figure 8) nearly two months later. This behavior (increasing temperature) was expected. However, the measured temperature of $\mathrm{TCl}$ of Riser 14 was higher than expected. Figure 8 shows the maximum waste temperature predicted by the process control model discussed in the previous section. This corresponds to the centerline temperature at the tank bottom. The predicted temperature for December 1998 and January of 1999 is $217^{\circ} \mathrm{F}$. This is lower than the measured Riser 14 maximum temperature. The predicted temperature should be larger at the tank center, since there is a radial temperature gradient between the tank centerline and Riser 14.

As discussed in the previous section, the predicted maximum waste temperature is a function of the initial starting temperature for the calculation and the predicted temperature change since the 1994 process test. The latter parameter has been benchmarked with actual tank data. The comparison of the thermal process control analyses with dome space and Riser 8 temperatures, showed that the temperature changes observed at Riser 8 and dome space are accurately predicted by the process control model, using measured ambient conditions, radionuclide decay and tank ventilation operating history. Nothing in the analyses or the temperature data from Riser 8 supports an increased heating of the waste (from decreased heat removal or increased heat generation) which might account for the unexpectedly high Riser 14 temperatures. The only reasonable explanation is an underestimate of the saturation temperature for the waste. 
Figure 8 Riser 14, TC1 And Predicted Maximum Waste Temperatures.

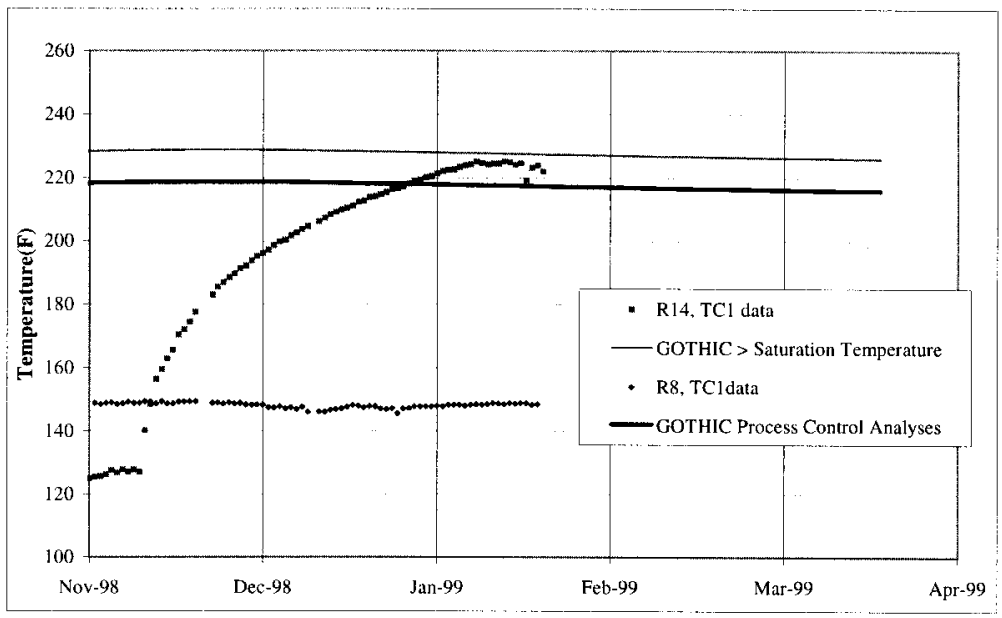

\subsection{EVALUATION OF THE WASTE SATURATION TEMPERATURE}

The saturation temperature for tank $241-\mathrm{C}-106$ has been re-evaluated using waste sample data not available at the time of the 1994 estimate. This re-evaluation supports a higher waste saturation temperature.

Grab samples of tank 241-C-106 were obtained in 1996. These samples were used to provide a revised estimate of the waste saturation temperature, based upon the expected vapor suppression of the waste (Reynolds 1999). Table 1 shows a summary of the saturation temperatures derived from an evaluation of the 1996 waste grab samples. Reynolds used the analytical information derived from the waste grab samples to determine chemical compositions that were then used as input to the $\mathrm{ESP}^{\mathrm{TM}}{ }^{2}$ computer program for analyses. The roughly $4{ }^{\circ} \mathrm{F}$ variation in saturation temperature for a given tank bottom pressure is due to differences in dissolved solids in the liquid samples.

These estimates are generally higher than 1994 Reynolds estimates. The 1994 estimates were based upon 1990 grab samples that were known to be more dilute than the 1996 samples. This accounts for the difference in estimated saturation temperatures.

\footnotetext{
${ }^{2}$ Trademark of OLI Inc., Morris Plains, NJ.
} 
The values shown in Table 1 are higher than the saturation temperature used in the initial process control thermal analyses $\left(230^{\circ} \mathrm{F}\right)$. Accounting for the variation in the samples, an upper bound estimate at 1.3 atmosphere bottom pressure (estimated bottom pressure based upon best estimate thermal parameters, Ogden et al. 1998b) would be from $235^{\circ} \mathrm{F}$ (based upon the average) to $238^{\circ} \mathrm{F}$ (average plus two standard deviations).

There are several factors which could result in an under estimate of the saturation temperatures. The grab samples were generally taken in riser locations that have previously been disturbed by equipment removal or waste sampling. This waste may not be a good representation of undisturbed waste near the center of the tank. Secondly, the method of taking and retrieving grab samples from the waste allows the possibility of dilution of the sample by the supernate pool. This may effect the estimation of saturation temperature if the sample is not representative of the actual waste composition. Both factors may contribute to an underestimation of the saturation temperature.

Table 1 Saturation Temperature Estimates Based 1996 Samples.

\begin{tabular}{|c|c|c|c|c|c|}
\hline आ4) & \multicolumn{4}{|c|}{ Botlom Arescure (A tmospheres) } & \\
\hline Sample 10 & 1 & 111 & 1.2 & 125 & 13 \\
\hline $6 C-96-4$ & 222.6 & 227.6 & 232.2 & 234.4 & 236.5 \\
\hline $6 \mathrm{C}-96-7$ & 220.1 & 225.0 & 229.6 & 231.8 & 233.9 \\
\hline $6 \mathrm{C}-96-1$ & 218.7 & 223.7 & 228.3 & 230.5 & 232.6 \\
\hline $6 \mathrm{C}-96-13$ & 221.1 & & & 233.0 & 235.1 \\
\hline
\end{tabular}

The estimation of the saturation temperature based upon 1996 waste samples provides support for a higher saturation temperature than used in the initial process control analyses. Based on the grab samples, the saturation temperature could be as high as 238 ${ }^{\circ} \mathrm{F}$ (The higher saturation temperature estimate supercedes the previous estimate Ogden et al. 1998b). Analyses were performed using the ESP ${ }^{\mathrm{TM}}$ program assuming that the saturation temperature was $240^{\circ} \mathrm{F}$. The ionic strength and the sodium concentration required to achieve the higher saturation temperature were well within the range of values seen in Hanford waste samples of similar waste. Thus, while the upper bound estimate for the saturation temperature is $238^{\circ} \mathrm{F}$, saturation temperatures in excess of $240^{\circ} \mathrm{F}$ can not be ruled out based upon vapor suppression considerations.

The GOTHIC process control predicted maximum waste temperatures were shown in Figure 8. These represent the tank bottom centerline temperature. The temperature gradient between the tank centerline and Riser 14 was previously calculated for 241-C106 with chiller operation and 1994 heat load (Ogden et al.1998b). The temperature difference was predicted to be $6{ }^{\circ} \mathrm{F}$. With radionuclide decay, this gradient should be just under $5{ }^{\circ} \mathrm{F}$ today. Given this temperature gradient, the waste saturation temperature and initial temperature for the process control analyses would need to be $242{ }^{\circ} \mathrm{F}$ to match the measured temperatures at Riser 14 . This is higher than the waste sample estimate but is not inconsistent with the possible range of waste saturation temperatures. 


\subsection{RECOMMENDED REVISION FOR RISER 14 TEMPERATURE LIMIT}

Process control thermal analyses are performed for tank 241-C-106 to demonstrate that adequate subcooling exists to safely sluice the waste with a liquid pool cover. This is the primary thermal process control parameter for tank 241-C-106.

Temperature limits were also established for Riser 8 and Riser 14. The Riser 8 temperature limit was established at $148^{\circ} \mathrm{F}$. This is the measured winter temperature for 1994. The temperature limit for $\mathrm{TCl}$ of Riser 14 is $218^{\circ} \mathrm{F}$. This limit was derived from the assumed waste saturation temperature, accounting for the radial temperature gradient, temperature measurement error and applying a margin of safety. The process thermal analyses are the bases for the estimate of waste subcooling. The riser temperature limits are intended as warning flags. If these limits are exceeded, sluicing may continue if the process thermal analyses indicated that adequate subcooling exists in the waste.

The Riser 14-temperature limit was exceeded in December of 1998 following the initial sluicing activities. Although the limit was exceeded, the process thermal analyses (Section 3.0) showed that adequate subcooling existed in the waste and that the previous estimate of saturation temperature, which is the basis for the temperature limit, was low (Section 4.2). A higher temperature limit for Riser 14 should be established. This limit could be based upon the revised saturation temperature limit, similar to the previous limit. The revised limit would be $225^{\circ} \mathrm{F}$ for an assumed saturation temperature of $236^{\circ} \mathrm{F}$ $\left(236^{\circ} \mathrm{F}\right.$ minus $5^{\circ} \mathrm{F} \mathrm{R}-14$ radial off-set correction and minus $6{ }^{\circ} \mathrm{F}$ thermocouple and display system error). An alternative method for establishing the limit is to base the limit upon the historic high reading for $\mathrm{TC} 1$ rather than the estimated saturation temperature. The primary thermal process control parameter is the waste subcooling. The thermal analyses showed that the bulk waste was subcooled a minimum of $10^{\circ} \mathrm{F}$ during and following the initial sluicing. Thus, the measured value of $225^{\circ} \mathrm{F}$ for TCl of Riser 14 is consistent with a subcooling of $10^{\circ} \mathrm{F}$. The new revised Riser 14 temperature limit should be set a $225^{\circ} \mathrm{F}$ based upon both the historic high for Riser 14, TCl and the revised saturation temperature. With further waste temperature reduction through the operation of the inlet chiller of the P-16 system, the Riser 14 temperatures are not expected to exceed a revised temperature limit of $225^{\circ} \mathrm{F}$. If the temperature limit is exceeded, adequate waste subcooling must be demonstrated through process control thermal analyses.

Similarly, the measured temperatures at Riser 8 slightly exceeded the $148^{\circ} \mathrm{F}$ temperature limit prior to sluicing. However, the process control thermal analyses showed that adequate subcooling existed in the waste for sluicing to proceed. The Riser 8 TC1 temperatures remain a few degrees above the temperature limit as shown in Figure 6. The process control thermal analyses have shown that these temperatures are consistent with $10^{\circ} \mathrm{F}$ of waste subcooling. Therefore, it is appropriate to raise the existing temperature limit. It is recommended that this limit be raised to $153^{\circ} \mathrm{F}$. This will provide a caution flag for the Riser 8 temperatures, while providing some operating 


\section{HNF-3941, Rev 1}

margin for measured temperatures which can apparently change by a few degrees during the sluicing operations. 


\subsection{CONCLUSIONS}

- The process control thermal model has been adequately benchmarked with tank data. It provides a good estimate of the temperature changes in the tank 241-C-106 waste since 1994-process test.

- The best estimate thermal analyses predict that there is more than $10^{\circ} \mathrm{F}$ subcooling, for the maximum temperature waste in tank 241-C-106. No regions of the waste are expected to be at saturation temperature.

- The possibility of small regions of saturated waste, with lower saturation temperatures or higher heat generation than the bulk waste is not precluded by the thermal analyses. However, the liquid pool covering during the first sluicing campaign will eliminate the disruption of these small saturation regions, should they exist. The subcooling achieved in the waste since the 1994 process test will assure that any possible saturation regions are small at best.

- The temperature responses of the Riser 14 thermocouples were expected. However, the actual maximum temperature was higher than predicted based upon previous estimates of the waste saturation temperature.

- The dome space and Riser 8 temperature data for tank 241-C-106 does not support an increase in heat generation or decrease in heat removal as an explanation for the high Riser 14 temperatures.

- An underestimate of the saturation temperature best explains the high Riser 14 temperatures. The re-evaluation of the saturation temperatures based upon 1996 waste, grab samples support this conclusion. A saturation temperature of $236^{\circ} \mathrm{F}$ is the best estimate.

- It is recommended that the Riser 14 process control temperature limit be increased to $225^{\circ} \mathrm{F}$.

- It is recommended that the Riser 8 process control temperature limit be increased to $153^{\circ} \mathrm{F}$. 


\subsection{REFERENCES}

Bander, T.J. 1995, Tank 241-C-106 Thermal Hydraulic Analysis to Establish the Cooling Liquid at a Minimum level, HWC-SD-WM-ER-495, Rev 0, Westinghouse Hanford Company, Richland, Washington.

Carothers, K.G., et. al., Tank 241-C-106 Waste Retrieval Sluicing System Process Control Plan, HNF-SD-WM-PCP-013, Rev 1, Lockheed Martin Hanford Corporation, Richland, Washington.

FDH 1998, Tank Waste Remediation System Safety Requirements, HNF-SD-WM-TSR006, Rev 1, Flour Daniel Hanford, Richland, Washington.

Ogden, D.M., Sathyanarayana, K., et. al 1998a, Project W-320 Thermal Hydraulic Model Benchmarking and Baselining, HNF-3196, Rev 0., Numatec Hanford Corporation, Richland, Washington.

Ogden, D.M., Sathyanarayana, K., et. al 1998b, Project W-320 SAR and Process Control Thermal Analyses, WHC-SD-W320-ER-004, Rev 1, Numatec Hanford Corporation, Richland, Washington.

Reynolds, D.A. 1994, Estimated Boiling Point of the Liquid in 24I-C-JO6, Reynolds to Kirch memorandum.

Reynolds, D.A. 1999, Environmental Simulation Program Boiling Point Estimates for Tank 241-C-106, Reynolds to Carothers memorandum.

Thurgood, M.J. and Fryer, B.C., 1995, Revised Tank Heat Load Estimate for Tank C-106 Based on GOTH Analysis of the Process Test, WHC-SD-ER-590, Rev 0, Westinghouse Hanford Company, Richland, Washington. 
HNF-3941, Rev 1

\section{APPENDIX A THERMAL ISSUE RESOLUTION MEETING} MINUTES 
A meeting was conducted on February 2, 1999 to discuss thermal issues related to the thermal evaluation of the Riser 14 temperatures presented in this report. The following is a list of attendees:

J. W. Bailey

J. M. Bates

K. G. Carothers

J. M. Cuta

B. C. Fryer

N. W. Kirch

D. M. Ogden

C. W. Stewart

M. J. Thurgood

R. G. Stickney

\section{Meeting Purpose}

The purpose of the meeting was to review the tank 241-C-106 thermal behavior since the start of sluicing and arrive at a consensus on how the thermal response represents the current tank conditions. It was generally agreed that during the 1992, ventilation outage, and the 1994 process test, significantly large regions of the waste were at or near saturation conditions with no evidence of steam bump behavior. It was also generally agreed that much less of the waste, if any of the waste, is at or near saturation conditions today.

\section{Group Consensus}

The consensus of the group is as follows:

1. The best estimate of the saturation temperature for $241-\mathrm{C}-106$ at the tank bottom is approximately $235^{\circ} \mathrm{F}$.

2. There may be some small region at or only slightly below saturation now.

3. However, the waste is generally $\sim 10^{\circ} \mathrm{F}$ cooler than during the summer 1994 (process test) condition.

4. It is prudent to continue sluicing with the liquid cover maintained.

5. The data indicate that waste around the R14 thermocouple may be at saturation at approximately $225^{\circ} \mathrm{F}$. However, it is likely that this waste filled in from above and has a lower $\mathrm{T}_{\text {sat }}$ than the undisturbed waste. 


\section{Discussion}

Figures 9 through 12 were presented at the meeting by C.W. Stewart. The figures show a correlation between barometric pressure changes and measured temperature changes at Riser 14. There was agreement that the figures indicated that a correlation seemed to exist. However, there was not agreement on the basis for the correlation. Figures 9 through 12 show a temperature decrease corresponding to the barometric pressure decrease. This is consistent with a decreasing saturation temperature near the thermocouple tree. However, Figure 9 shows that the waste near thermocouple 2, which is much lower in temperature, also decreases in temperature. In addition, Figure 10 shows that some of the temperature changes which are correlated to the pressure changes are much larger than the expected change in saturation temperature. This may be evidence that the temperature changes are the result of heat transfer changes around the thermocouple tree. It could also be the result of vapor generation and condensation dynamics. Whichever explanation is more appropriate, the temperature response time ensures that the phenomenon is occurring in a small region very near the thermocouple tree.

The mechanism for trapping vapor in the waste and the potential for spontaneous steam bumps were also discussed. There was not however a consensus on this subject, which is not directly related to the evaluation of the Riser 14 temperature response and waste subcooling. 
Figure 9 Temperature Response of Thermocouples 1 \& 2 of Riser 14.

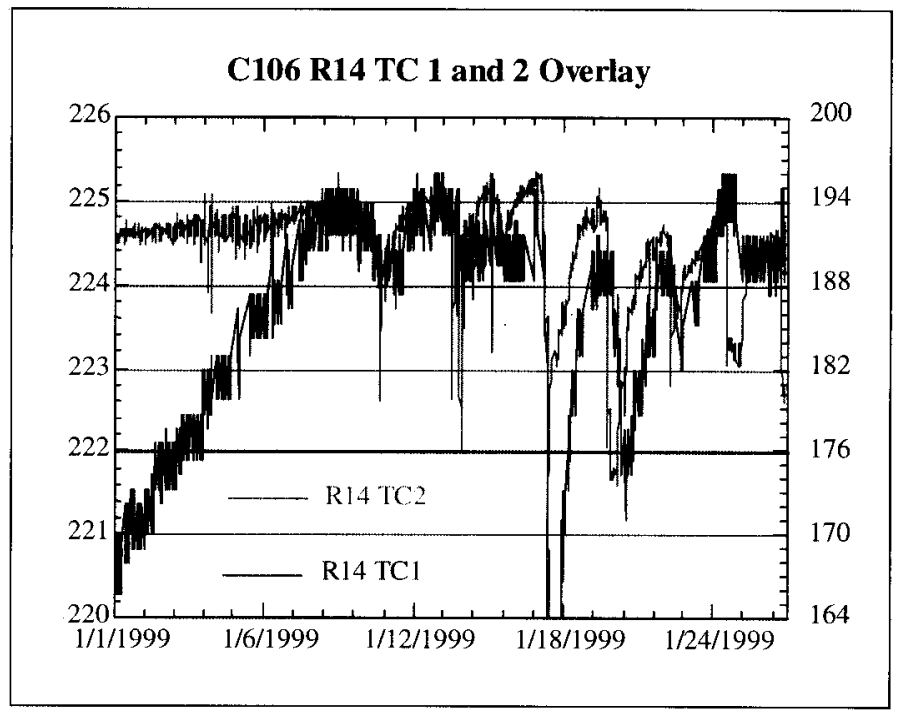


Figure 10 Effects of Barometric Pressure on Riser 14 Temperature

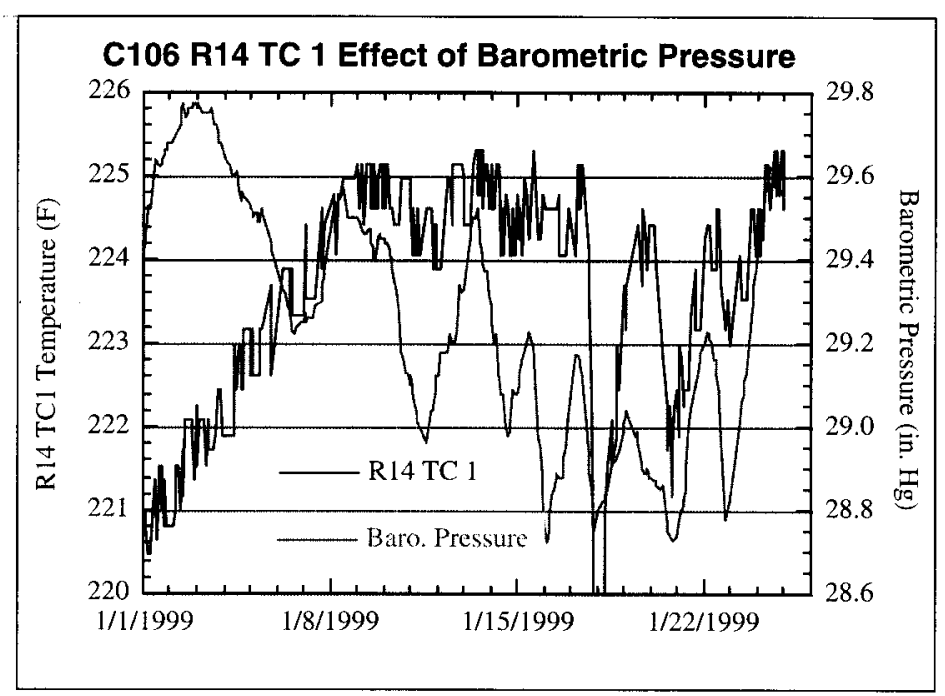


Figure 11 Barometric Pressure Effects

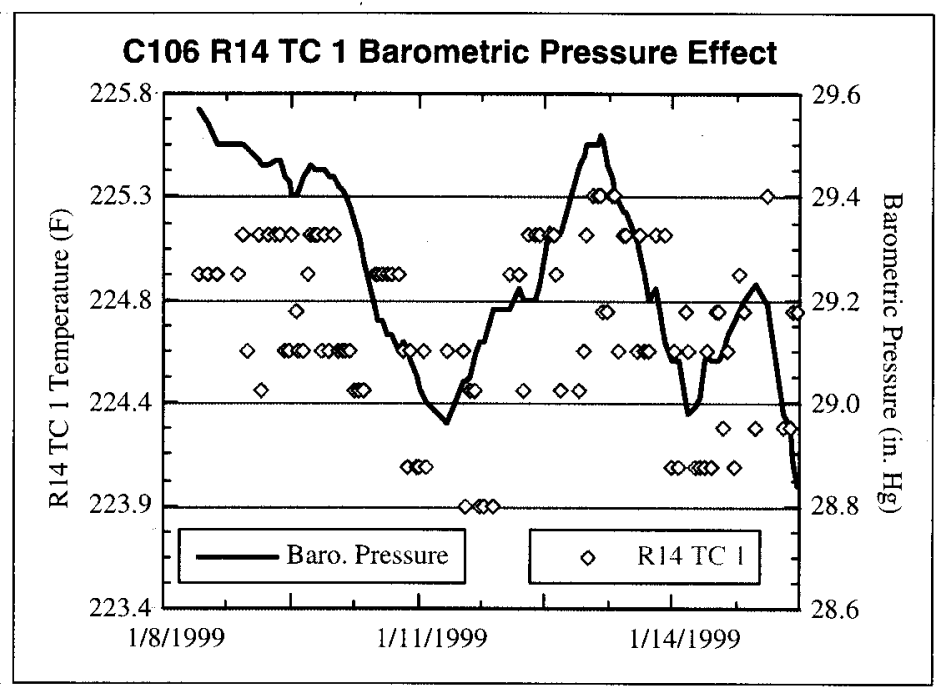


Figure 12 Pressure - Temperature Correlation

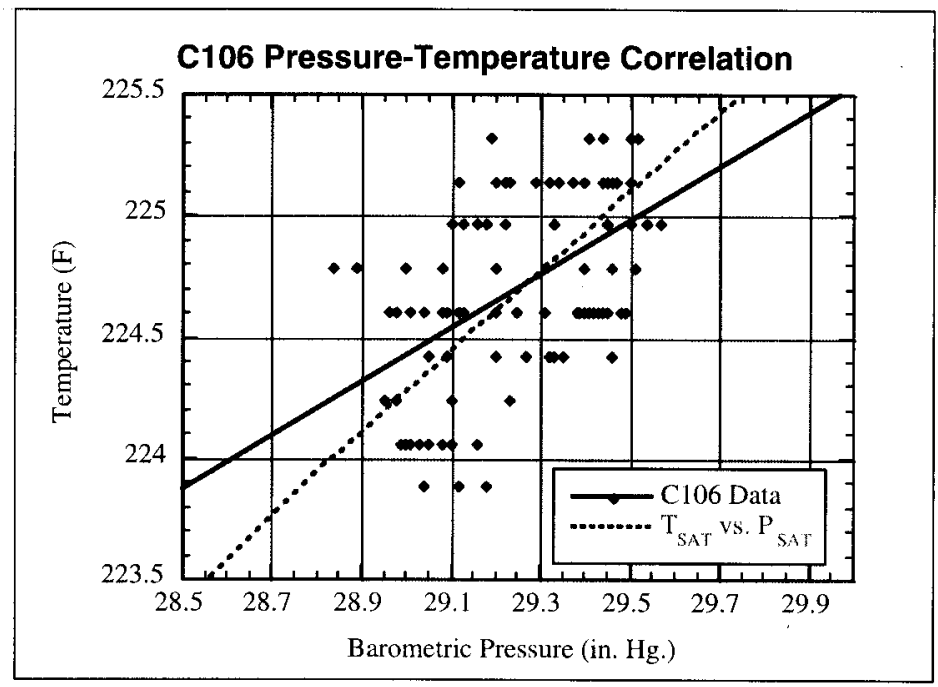

